\title{
Distribution of the assemblage of phlebotomine sandflies (Diptera: Psychodidae) along an environmental gradient
}

\author{
Yasmine Antonini ${ }^{\text {*, G. Wilson Fernandes }}{ }^{2}$ \& Ricardo Andrade Barata ${ }^{3}$ \\ ${ }^{1}$ Universidade Federal de Ouro Preto, Instituto de Ciências Exatas e Biológicas, Departamento de Biodiversidade, \\ Evolução e Meio Ambiente, Campus Morro do Cruzeiro, s/n, Ouro Preto, Minas Gerais, Brazil \\ ${ }^{2}$ Universidade Federal de Minas Gerais, Instituto de Ciências Biológicas, Belo Horizonte, MG, Brazil \\ ${ }^{3}$ Universidade Federal dos Vales do Jequitinhonha e Mucuri, Diamantina, MG, Brazil \\ *Corresponding author: Yasmini Antonini, e-mail: antonini.y@gmail.com
}

ANTONINI, Y., FERNANDES, G. W., BARATA, R. A. Distribution of the assemblage of phlebotomine sandflies (Diptera: Psychodidae) along an environmental gradient. Biota Neotropica. 17(2): e20160253. http://dx.doi. org/10.1590/1676-0611-BN-2016-0253

\begin{abstract}
The geographical distribution of leishmaniasis has undoubtedly expanded, and is now being reported to be in areas that were previously non-endemic. This study therefore aimed to investigate whether there is any variation in the structure and in the composition of phlebotomine communities along an environmental gradient - from a mesic to a xeric environment, across different climatic periods (rainy and dry seasons). Furthermore, we test whether there were differences in sex ratio of sand flies between wet and dry environments. A total of 535 specimens of sand flies belonging to 18 species were recorded. Richness, abundance, and composition of species were significatively higher in the xeric environment (semidecidual Forest) compared to the mesic environment (Riparina Forest). We unveiled site specific differences in sand fly collections since the community composition changes with the geographic distance among the sampling points. These results led to the conclusion that for sand flies species, the environmental conditions available for each species could be different within the habitat taking into account the degree of humidity in the forest as well as the climatic season (dry or wet). The present study gives a valuable contribution to the knowledge of sand flies, as a group of insects, from the Atlantic Forest biome.
\end{abstract}

Keywords: Species composition, ecology, leishmaniasis, Atlantic Forest, Brazil

\section{Distribuição da assembléia de flebotomíneos (Diptera: Psychodidae) em um gradiente ambiental}

\begin{abstract}
Resumo: A distribuição geográfica das leishmanioses, sem dúvida, tem se expandido, e agora está sendo relatada em áreas previamente consideradas como não endêmicas. Assim, este estudo teve como objetivo investigar se existe alguma variação na estrutura e na composição das comunidades de flebotomíneos ao longo de um gradiente ambiental - em habitats classificados como mesicos e xericos, em diferentes períodos climáticos (chuva e seca). Além disso, testamos se havia diferenças na razão sexual entre ambientes mais umidos e mais secos. Um total de 535 espécimes de flebotomíneos pertencentes a 18 espécies foram registradas. Riqueza, abundância e composição de espécies foram significativamente maiores nos habitats xericos (Floresta semidecidual) em comparação com os habitats mesicos (Floresta Ciliar). Revelamos diferenças específicas entre os habitats, nas assembleias de flebotomíneos, uma vez que a composição da comunidade muda com a distância geográfica entre os pontos de amostragem. Estes resultados levaram à conclusão de que as condições ambientais disponíveis para cada espécie de fletomonineo varia dentro do habitat, tendo em conta o grau de umidade na floresta assim como a estação climatica (seca-chuva). O presente estudo dá uma contribuição valiosa para o conhecimento da fauna de flebotomíneos, no bioma Mata Atlântica.
\end{abstract}

Palavras-chave: Composição de espécies, ecologia, leishmanioses, Floresta Atlântica, Brasil

\section{Introduction}

Phlebotomine sand flies are vectors of pathogenic organisms, such as Leishmania, in many regions of Brazil, which has been a major endemic focus of leishmaniasis for many years. The transmission of the Leishmania parasite species to the vertebrate host, occurs when the vertebrate host is bitten by infected female sand flies (Sherlock 2003). The geographical distribution of leishmaniasis has undoubtedly expanded, and is now being reported in areas that were previously known to be non-endemic (McCarthy et al. 2013).

The resting places of the adult sand flies vary, depending on the species and to on the habitat conditions such as forest floor (litter fall), 
small shrubs and plants, mammal nests and burrows, as well as rock crevices (Young \& Duncan 1994). In general, the activity period of sand flies ranges from dusk to dawn, and these insects remain at rest in natural shelters during most part of the day.

Sand flies are very sensitive to environmental changes. In this regard, soil type, land use and modification of natural habitats are critical factors affecting changes in the vector, reservoir population densities, and risks posed by leishmaniasis (Rangel \& Lainson 2009).

The understanding of the variation in the community of phlebotomine is of major importante due to the impact it causes in human health and economy. One way of understanding these flies importance is through the description of the variation in their communities in space and time. A better understanding of beta-diversity patterns and their causes, demonstrates that, it has important practical implications for biodiversity conservation as well as the planning and interpretation of ecological research (Tuomisto et al. 2003). Unfortunately, there are very few surveys of the phlebotomine fauna in natural systems that address beta-diversity, despite being fully aware of the importance of these studies in increasing our knowledge of areas where these insects can be found and in minimizing human contact with them.

We evaluated the influence and the relative importance of spatial and environmental factors in explaining the variations on phlebotomine species richness and composition. This study, therefore, aimed to investigate whether there is any variation in the structure and composition of the phlebotomine communities, along an environmental gradient - from Mesic (riparian forest) to a xeric (se midecidual forest) environment and to determine species richness and abundance in those environments. We hipotetize that the richnes and abundance will be higher in mesic enviroments and that the composition of the sand fly assemblage will be different with the distance among the sampling areas.

\section{Material and Methods}

\section{Study area}

The study was carried out in fragments of forest on the Santo Antônio de Pádua municipality, in the Rio de Janeiro state, Brazil (Figure 1). The vegetation in the area consists of fragments of riparian forest (mesic habitat)- along the Rio Pomba River, and small fragments of semidecidual Atlantic forest located at the top of small hills (xeric habitat) (IBGE 1992). The climate is classified into Köppens Aw Tropical (Alvares et al. 2013) with dry winter. Total annual rainfall is high, around $1600 \mathrm{~mm}$. Temperatures are high throughout the year (average temperature is $26^{\circ} \mathrm{C}$ ) with little variation.

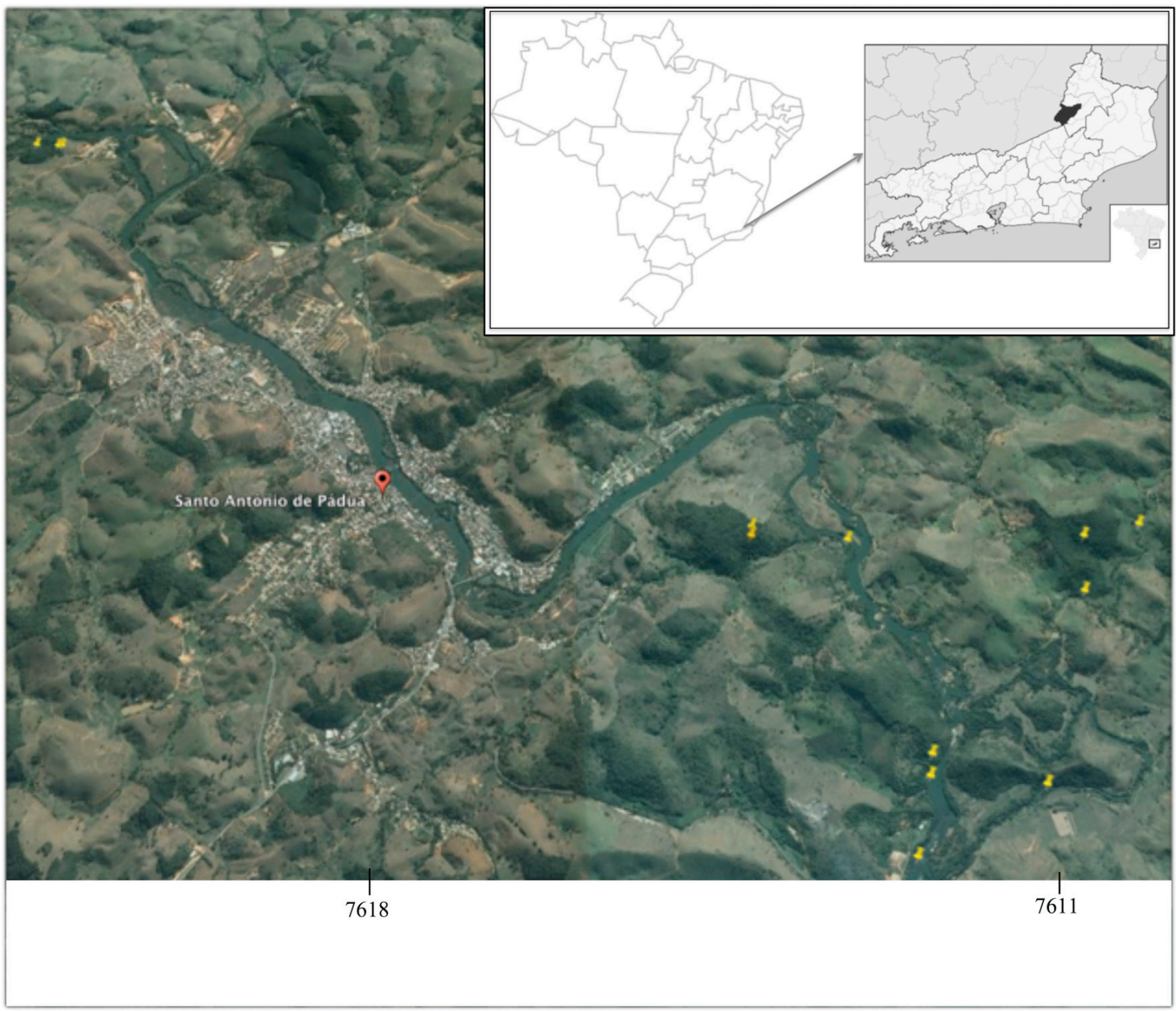

Figure 1. Map showing collecting localities of sand flies at the Santo Antonio de Pádua municipality, State of Rio de Janeiro, southeastern of Brazil. Coordinates in UTM. The yellow pins represent the location for each transect. Source of Map: Google Maps Pro. 


\section{Sampling}

Four fragments of forest were selected for this study, being two of riparian forests and two of semideciduous forests. In each fragment, insects were captured in transects of $100 \mathrm{~m}$ (Figure 1). For the purposes of this study, each transect has been categorized according to the vegetation type - wet or mesic (riparian forest - hereafter, referred to as WE) and dry or xeric (semideciduous forest - hereafter, referred to as DE).

Three HP light traps (Pugedo et al. 2005) were installed along each of these transects, at $20 \mathrm{~m}$ intervals. The traps were installed at $6 \mathrm{pm}$ and collected at 6 am the following morning, in two sampling events -14 th to 18th February (wet season) and May 30th to June $3^{\text {rd }}$ of 2013 (dry season), giving a total sampling effort of $72 \mathrm{~h} /$ fragment. The collection was made under ICMBIO permition (10717-1) conceived to Y.A.

The collected phlebotomines were cleared in $10 \%$ potassium hydroxide, acetic acid, distilled water and lactophenol, and mounted in Berlese fluid (Langeron 1949). They were later identified according to Young \& Duncan (1994) and Martins et al. (1978). Specimens with missing or damaged characters that impaired identification at the specific level were considered as Lutzomyia sp. The females belonging to Brumptomyia genera were not identified at the specific level and were considered as Brumptomyia sp..

\section{Statistical analyses}

The relationship between the two types of environmental gradients and the species richness and abundance of the specimens collected in the fragments inside each environment was analyzed using a one-way ANOVA. A $t$-test was used to determine whether the average male and female abundance was statistically different. The specimens that where not identified to the species level or morphotype, were considered as belonging to one same species in the model.

Permutational Analysis of Variance (PERMANOVA) was used to test the hypothesis which states that, the composition of sand flies varies between gradients of humidity wet (WE) and dry (DE). The measure of dissimilarity used was that of Bray-Curtis with 1,000 permutations, and in measuring the dispersion of the data, multivariate analyses of Permutation Distance (PERMDISP) were performed. The graphical representation of the variation in the composition of sandflies assemblages between seasons and among sampling units was illustrated by the analysis of Non-metric Multidimensional Scaling (NMDS).

The relationship between geographic distance and similarity in species composition, also known as the distance-decay in similarity relationship, was analyzed using simple linear regressions. A distance-decay plots was built (Nekola \& White 1999), in order to analyze the variation in the compositional similarity among pairs of sampling sites, in relation to the geographic distance and to the climatic distance among these sites. The geographic matrix was built using the Euclidean distance between sites, based on their distances (in Km), and also using the Google Maps Pro.

\section{Results}

A total number of 535 phlebotomine specimens belonging to 18 species were recorded (Table 1). The following species were captured: Brumptomyia avellari (Costa Lima, 1932), B. guimaraesi (Coutinho \& Barretto 1941), B. nitzulescui (Costa Lima 1932), Lutzomyia capixaba Dias, Falcão, Silva \& Martins 1987, Lu. cortelezzii (Brethes 1923), Lu. christenseni Young \& Duncan 1994, Lu. edwardsi (Mangabeira 1941), Lu. intermedia (Lutz \& Neiva 1912), Lu. lutziana (Costa Lima 1932), Lu. migonei (França 1920), Lu. minasensis (Mangabeira 1942), Lu. pascalei (Coutinho \& Barretto 1940), Lu. quinquefer (Dyar, 1929), Lu. sallesi (Galvão \& Coutinho 1939), Lu. sordellii (Shannon \& Del Ponte 1927), and Lu. tupynambai (Mangabeira 1942). Lutzomyia intermedia accounted for $43 \%$ of all specimens sampled, while Brumptomyia avellari and Brumptomyia sp. accounted for $37 \%$ of sampled specimens. The remaining species together, accounted for $20 \%$.

A total number of 294 males (55\%) and 241 females (45\%) were collected (Table 1). Despite the proportion of male was slightly higher than that of female (Table 1), we did not find any significant difference between male and female abundance. The sexual ratio of the assemblage was 1:0.8. The difference in sex ratio was higher in WE2 - for DE1 and DE3, there is no difference (Figure 2A).

There was significant difference in species richness $\left(\mathrm{ANOVA}_{1,16}=5.07\right.$, $\mathrm{P}=0.025)$ and abundance $\left(\mathrm{ANOVA}_{1,16}=7.34, \mathrm{P}<0.001\right)$ within the sampling sites (Figure 2B). Higher richness and abundance was found on transects in xeric environments (Figure 2B).

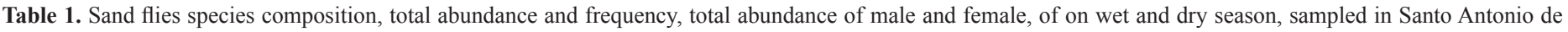
Padua Municipality, RJ, Brazil.

\begin{tabular}{|c|c|c|c|c|c|c|}
\hline \multirow{2}{*}{ Species } & \multicolumn{2}{|c|}{ Climatic station } & \multicolumn{2}{|c|}{ SEX } & \multirow{2}{*}{ Total (N) } & \multirow{2}{*}{$\%$} \\
\hline & Wet & Dry & 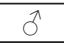 & q & & \\
\hline Brumptomyia avellari & 80 & 20 & 100 & - & 100 & 18.7 \\
\hline B. nitzulescui & 5 & 0 & 5 & - & 5 & 0.9 \\
\hline B. guimaraesi & 15 & 3 & 18 & - & 18 & 3.3 \\
\hline Brumptomyia sp. & 72 & 24 & 3 & 93 & 96 & 17.9 \\
\hline Lutzomyia capixaba & 1 & 0 & 0 & 1 & 1 & 0.2 \\
\hline Lu. cortelezzii & 5 & 0 & 2 & 3 & 5 & 0.9 \\
\hline Lu. christenseni & 1 & 0 & 0 & 1 & 1 & 0.2 \\
\hline Lu. edwardsi & 3 & 1 & 1 & 3 & 4 & 0.8 \\
\hline Lu. intermedia & 226 & 4 & 146 & 84 & 230 & 43.0 \\
\hline Lu. lutziana & 15 & 4 & 8 & 11 & 19 & 3.6 \\
\hline Lu. migonei & 5 & 0 & 4 & 1 & 5 & 0.9 \\
\hline Lu. minasensis & 1 & 0 & 1 & 0 & 1 & 0.2 \\
\hline Lu. pascalei & 1 & 0 & 1 & 0 & 1 & 0.2 \\
\hline Lu. quinquefer & 6 & 1 & 2 & 5 & 7 & 1.3 \\
\hline Lu. sallesi & 2 & 1 & 3 & 0 & 3 & 0.6 \\
\hline Lu. sordellii & 4 & 0 & 0 & 4 & 4 & 0.8 \\
\hline Lu. tupynambai & 13 & 16 & 0 & 29 & 29 & 5.4 \\
\hline Lutzomyia sp. & 4 & 2 & 0 & 6 & 6 & 1.1 \\
\hline Total & 459 & 76 & 294 & 241 & 535 & 100 \\
\hline
\end{tabular}



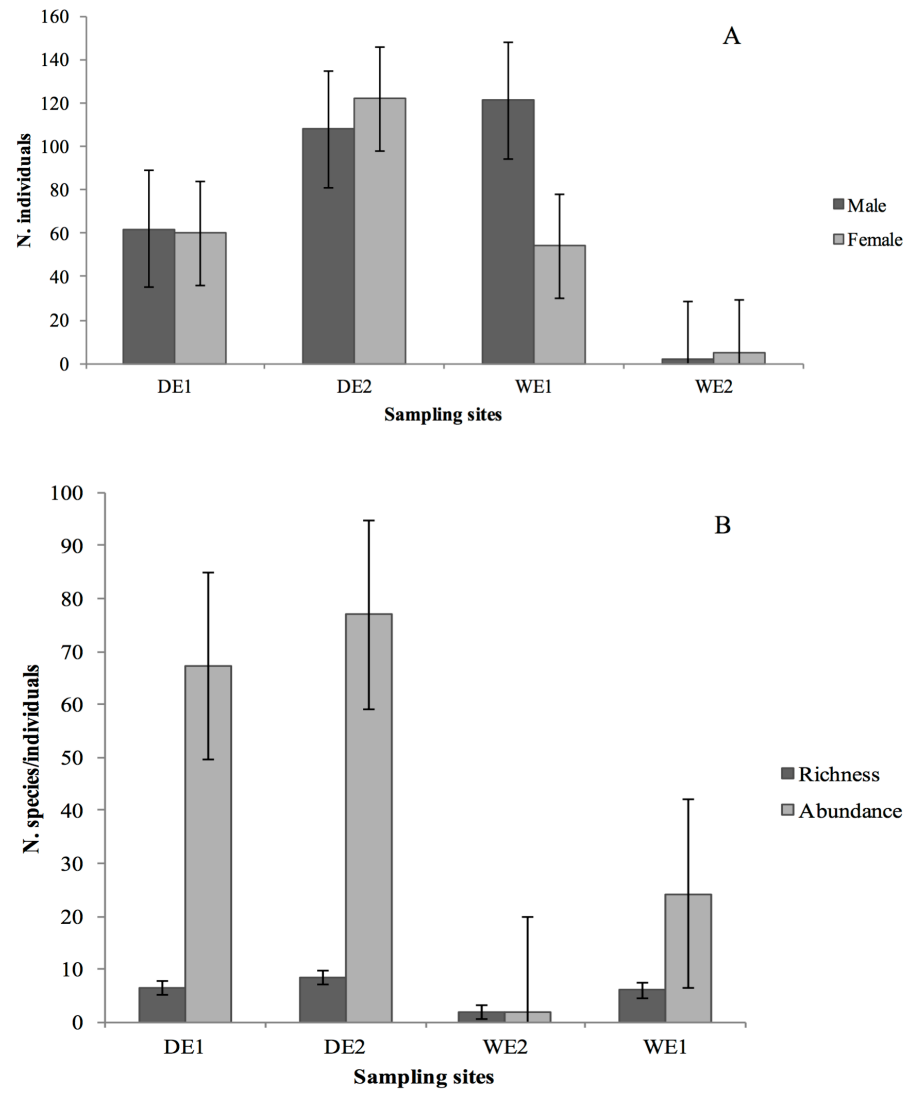

Figure 2. Total abundance of male and female (A) and total richness and abundance (B) of phlebotomine sand flies, and at the four sampling sites, Santo Antonio de Pádua, RJ, Brazil. DE - Dry environment, WE - Wet environment. Bars are means \pm SE.

The level of pairwise similarity among the 11 sand flies communities sampled, was highly variable, ranging from $0 \%$ to $73 \%$ (Bray-Curtis index, mean $=33.8 \%$ ), considering the presence or absence of all recorded species. Similarity in the composition of sand flies species among the different pairs of transects decayed as function geographic distances among sites $(\mathrm{r}=-0.42, \mathrm{P}<0.01)$ (Figure 3).

During the wet season, 459 specimens belonging to all 18 sampling species $(85.7 \%)$ were collected while during the dry season, 76 individuals $(14.3 \%)$ belonging to 10 species (Table 1$)$ were collected. The two most abundant species during the wet season were L. intermedia and B. avellari. In dry season, Brumptomyia sp., B. avellari and L. tupynambai were the most abundant (Table 1).

The composition of sand flies species varied between xeric and mesic habitats (Permanova, $\mathrm{R}^{2}=0.2293, \mathrm{P}=0.038$; Permidisp, $\mathrm{F}=5.72, \mathrm{p}<0.03$ ) (Figure 4). The similarity in species composition between dry and wet climatic period was $55 \%$. The NMDS analyzes show that even the transects on the same area present different composition of species (Figure 4), however, there is a clear spatial separation on species composition, between xeric and mesic environments. The species with the widest distribution, which were found in 10 out of 13 transects, both in mesic and xeric were B. avellari and $L$. intermedia are responsible to group sampling sites DE1 with all WE.

\section{Discussion}

The number of species found in this study can be considered high. Currently, the sand fly fauna of Rio de Janeiro State has 65 species, belonging to the genera Brumptomyia (8 spp.) and Lutzomyia (57 spp.) (Carvalho et al. 2014). It is important to notice that the richness could be

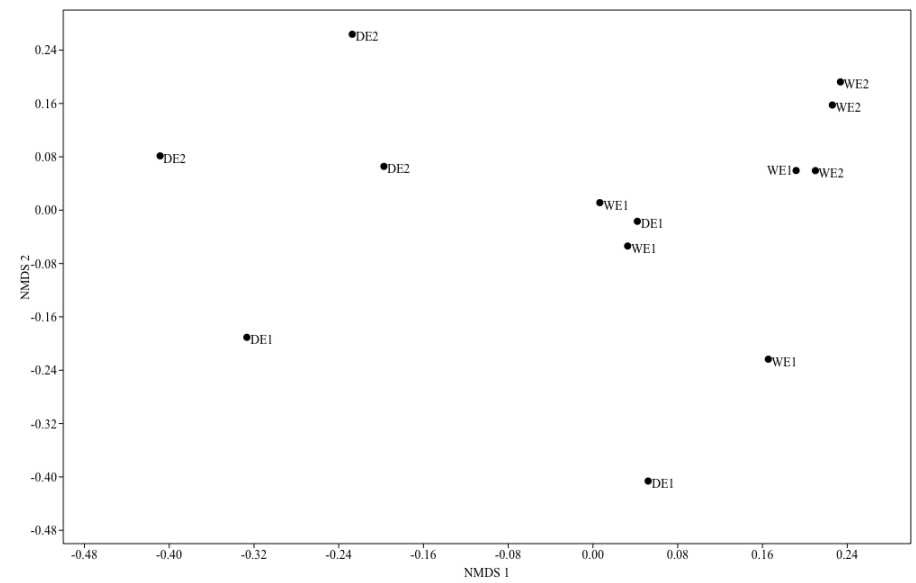

Figure 3. NMDS showing the species composition of phlebotomine sand flies in transects in Dry Enviroments (DE) and Wet Enviroments (WE), Santo Antonio de Padua, RJ. Brazil.

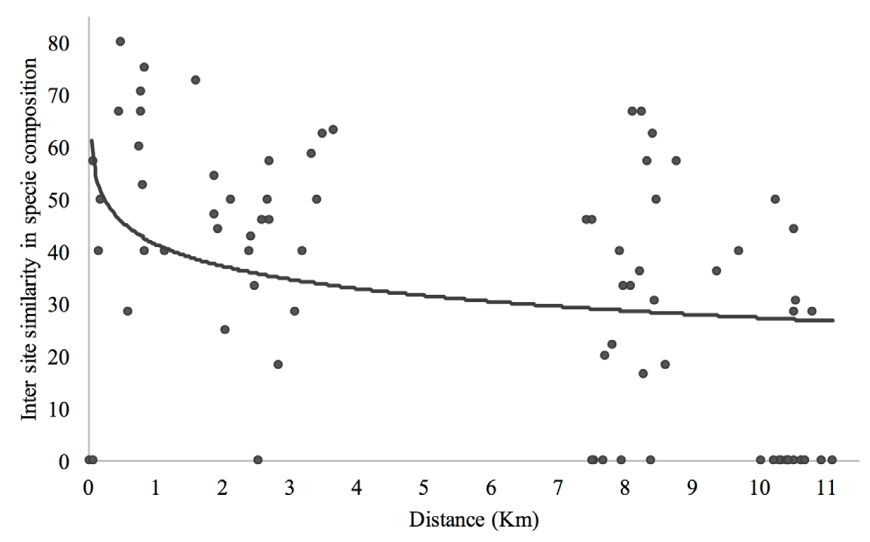

Figure 4. Decay in the similarity of phlebotomine sand flies assemblages in relation to the geographic distance between sampling sites. Geographic distance is the distance in $\mathrm{km}$ between pair sites. Similarity in orchid-bee species composition is based on the Bray-Curtis index of similarity. Line represent the logarithmic regression curve.

higher, if the 96 individuals of Brumptomyia could be identified to the species level. To the best of our knowledge, only the occurrence of $L$. intermedia had been reported in the study area (Rangel et al. 1984). Yet, the report of L. intermedia and L. migonei in such areas is important because these species are known to be vectors of cutaneous leishmaniasis agents (Lainson 1985, Pita-Pereira et al. 2005). Lutzomyia intermedia seems to play an important role in the transmission mechanism of American Cutaneous Leishmaniasis, due to their high degree of antrophofily and abundance, in many Brazilian regions, including Rio de Janeiro (Rangel \& Lainson 2009), where it has been found to be naturally infected with Leishmania, presumably $L$. $(V$.) braziliensis (Rangel et al. 1984). According to Carvalho et al (2014) the lists of sand flies of the state of Rio de Janeiro, shows records of sand fly species from 46 municipalities. Otherwise the lists corresponds to only $50 \%$ of the 92 municipalities of Rio de Janeiro State, and that some other species could certainly be found in other areas with future studies.

The abundance of male and female, considering the whole assemblage, is almost 1:1. However, between sites, and seasons, there were significant differences. On WE1, we found the highest proportion of males, compared to females. The higher proportion of males in the population have been previously reported and this corroborates the results obtained in studies 
involving sampling of phlebotomines using light trap (Dye et al. 1991, Barata et al. 2004, Rosario et al 2017). For example, male sand flies are attracted to plants as a source of sugar meals. Plants also provide suitable resting, breeding and mating sites for males (Rangel \& Lainson 2009).

In the present study, species richness varied a little among different environments on the same category of humidity, although, there were some differences in species composition between them. Indeed, some species are only present in a single site, at a very low density. The capture of certain species in a reduced number and their presence in only one of the studied areas, leads us to believe that among sand flies, differentiated degrees of adaptability might occur in disturbed environments and in isolated habitats due to land use expansion (Ready et al. 1983). Other studies showed a similar pattern; the phlebotomine fauna is composed of a few dominant species and a large number of species with few individuals (see Silva et al 2010, Barata et al 2011, Rosario et al 2017). Further studies must be undertaken, so as to evaluate the impact of anthropogenic environment on the wild flora and fauna of these ecosystems, by considering aspects of behavior, physiology and dispersion of these insects, in order to elucidate the changes, as to the dominance and the composition of the entomological fauna observed in the present study.

It was expected that on WE, the abundance of sand flies would be higher than the driest environment, due to its proximity to the river. While certain sand fly species exhibit local extinctions, others are predicted to adapt successfully as well as increase their relative abundance in modified habitats. That is the case of L. intermedia and L. whitmani, found in our study. Rangel and Lainson (2009) reported and relate environmental changes to the modification on phlebotomines habitat. All of these factors also affect the spatial and temporal distribution of vectors and reservoirs, which in turn, affect the epidemiology and dynamics of pathogen transmission to the human population. It is important to note that, contrary to the semidecidual fragments of forest sampled in this study, the remnants of Riparian Forest are heavily impacted by human activities and most part of the forest have been completely converted into pastures or agriculture fields (Yasmine Antonini, pers. obs). The same result was found in other studies in forest fragments (Azevedo et al. 2011). According to Martin \& Rebêlo (2006), this low frequency may be associated with various factors, such as the absence of a source of blood meals and shelters around the vicinity of the collection points, and the small area of influence of the light traps $(5 \mathrm{~m}$ ) (Dye et al. 1991). Nonetheless, some species exist naturally at very low densities, and their populations can, therefore, suffer considerable reductions in size of small fragments, making them more vulnerable to local extinction.

The species composition changes from the wet to the dry season, and also among sampling sites. The low similarity is an evidence of high seasonality of the assemblage. Lutzomyia intermedia, for example, is very seasonal, presenting a higher abundance during wet season. Regarding seasonality, previous studies also reported a higher frequency of $L$. intermedia in wet and warmer months (Gouveia et al. 2012). Lutzomyia migonei, L. lutziana and Brumptomyia sp. were also found in higher abundance during this period. It can be concluded that the seasonal distribution of phlebotominae vectors could be influenced by the characteristics of their environment (Barata et al. 2011).

The low similarity between pairs of habitats, taking into account, the distance, was expected, and our results are in agreement with a growing body of evidence (Ruokolainen et al. 2007; Vasconcelos et al. 2010) which demonstrates that environmental gradients affect the turnover of plant species and invertebrates stronger in the tropical forests than in geographic gradients.

Studies in which the environment was managed to reduce contact with phlebotominae vectors, indicate that the environment can influence seasonal and spatial distributions of vectors (Gouveia et al. 2012, Souza et al. 2015). In the present study, B. avellari and L. tupynambai are projected to have the greatest increase in range size over time, perhaps due to the higher abundance both in DE and WE. The generalist behavior on habitat selection, which was formerly reported for other sand flies species should also be considered (Souza et al. 2015). Brumptomyia species are broadly distributed in America, occurring mainly in forested areas and constitute the group of sand flies commonly associated with armadillo burrows (Martins et al. 1978).

The results presented demonstrated a very dissimilar composition of sand flies in the two habitats (wet and dry). We found that there are site specific differences in sand fly collections. These observations led to a conclusion that environmental conditions available for each species could be different across the environments, taking into account the degree of humidity. The result of this analysis could be explained by the behavioral differences that exist between the most abundant species of the two environments.

The entomologic biodiversity of the Atlantic Forest, the most impacted vegetation type in Brazil, is not completely known and for sand flies, there are few studies. According to the Fundação SOS Mata Atlântica, the remnants of forest in Rio de Janeiro State is less than $10 \%$ of the original Biome. The findings presented in this study make up the first information regarding the sand fly fauna found in these forest fragments in the Atlantic Forest and contribute to the knowledge on this insect group distribution, as well as to the better understanding of the leishmaniasis vector epidemiology in the Southeastern region. The present study brings an important contribution to the knowledge of sand flies, as a group of insects and the potential threats imposed by them in animal population due to disease transmission, in the the Atlantic Forest biome. It also creates more awareness on the importance of maintaining these forest areas for the balance of the entomological populations and their interaction with the neighboring community.

\section{Acknowledgments}

Roberth Fagundes for their help during field collection. CNPq provided a scholarship to YA and to GWF. The English version was revised by Manuscript Proof Reading and by Erik Wild.

\section{Author Contributions}

Y. ANTONINI: Contribution in the concept and design of the study, data collection, data analysis and interpretation and manuscript preparation.

R. BARATA: Contribution in the analysis and interpretation and manuscript preparation.

G.W. FERNANDES: Contribution to critical revision, adding intelectual content.

\section{Conflict of Interest}

The authors declares that they have no conflict of interest related to the publication of this manuscript.

\section{References}

ALVARES C.A., STAPE J.L., SENTELHAS P.C., GONÇALVES J.L.M., SPAROVEK G. 2013. Koppen's climate classification map for Brazil. Meteorologische Zeitschrift 22: 711-728.

AGUIAR G.M., SCHUBACK P.A., VILELA M.L., AZEVEDO A.C.R. 1985. Aspectos da ecologia dos flebótomos do Parque Nacional da Serra dos Órgãos, Rio de Janeiro. II - Distribuição vertical (Diptera, Psychodidae, Phlebotominae). Mem Inst Oswaldo Cruz 80: 187-194.

AGUIAR G.M., MEDEIROS W.M., SANTOS T.G., KLEIN A.F.L., FERREIRA V.A. 1993. Ecology of sandflies in a recent focus of cutaneous leishmaniasis in 
Paraty, litoral of Rio de Janeiro State (Diptera: Psychodidae: Phlebotominae) Mem Inst Oswaldo Cruz 88: 339-340.

AZEVEDO P.C.B., LOPES G.N., FONTELES R.S., VASCONCELOS G.C., MORAES J.L.P., REBELO J.M.M. 2011. The effect of fragmentation on phlebotomine communities (Diptera: Psychodidae) in areas of ombrophilous forest in São Luís, State of Maranhão, Brazil. Neotrop Entomol 40: 271-277.

BARATA R.A., PAZ G.F., BASTOS M.C., ANDRADE R.C.O., BARROS D.C.M., LARA-SILVA F.O., MICHALSKY E.M., PINHEIRO A.C., DIAS E.S. 2011. Phlebotomine sandflies (Diptera: Psychodidae) in Governador Valadares, a transmission area for American tegumentary leishmaniasis in state of Minas Gerais, Brazil. Rev Soc Bras Med Trop 44: 136-139.

CARVALHO B.M., DIAS C.M.G., RANGEL E.F. 2014. Phlebotomine sand flies (Diptera, Psychodidae) from Rio de Janeiro State, Brazil: Species distribution and potential vectors of leishmaniases. Revista Brasileira de Entomologia 58: 77-87

DYE C., DAVIES C.R., LAINSON R. 1991. Communication among phlebotomine sandflies: a field study of domesticated Lutzomyia longipalpis populations in Amazonian Brazil. Anim Behav 42:183-192.

DORVAL M.E.C., CRISTALDO G., ROCHA H.C., ALVES T.P., ALVES M.A., OSHIRO E.T., OLIVEIRAA.G., BRAZIL R.P., GALATI E.A.B., CUNHA R.V. 2009. Phlebotomine fauna (Diptera: Psychodidae) of an American cutaneous leishmaniasis endemic area in the state of Mato Grosso do Sul, Brazil. Mem Inst Oswaldo Cruz 104: 695-702.

GOUVEIA C., OLIVEIRA R.M., ZWETSCH A, MOTTA-SILVA D., CARVALHO B.M., SANTANA A.F., RANGEL E.F. 2012. Integrated tools for American Cutaneous Leishmaniasis surveillance and control: intervention in an endemic area in Rio de Janeiro, RJ, Brazil. Interdiscip Perspect Infect Dis 2012: 1-9.

LAINSON R. 1985. Our present knowledge of the ecology and control of leishmaniasis in the Amazon Region of Brazil. Rev Soc Bras Med Trop 18: 47-56.

LANGERON M. 1949. Précis de Microscopie. Masson et Cie, Libraires de L'Académie de Medicine, Saint-Germain, Paris, 1.

MARTINS A.V.P., WILLIAMS P., FALCÃO A.L. 1978. American sand flies (Diptera, Psychodidae, Phlebotominae). Academia Brasileira de Ciências, Rio de Janeiro, Brazil. 195p.

MARTINA.M.C., REBÊLO J.M.M. 2006. Dinâmica espaço-temporal de flebotomíneos (Diptera, Psychodidae) do município de Santa Quitéria, área de cerrado do estado do Maranhão, Brasil. Iheringia Ser Zool 96: 273-384.

MCCARTHY C.B., SANTINI M.S., PIMENTA P.F.P., DIAMBRA L.A. 2013. First comparative transcriptomic analysis of wild adult male and female Lutzomyia longipalpis, vector of Visceral Leishmaniasis. Plos One 8(3): e58645.

NEKOLA J.C., WHITE P.S. 1999. The distance decay of similarity in biogeography and ecology. J Biogeography 26: 867-878.

ODORIZZI R.M.F.N., GALATI E.A.B. 2007. Flebotomíneos de várzea do rio Aguapeí, região noroeste do Estado de São Paulo, Brasil. Rev Saúde Pública 41: 645-52.

PITA-PEREIRA D., ALVES C.R., SOUZA M.B., BRAZIL R.P., BERTHO A.L., FIGUEIREDO B.A., BRITTO A.C.C. 2005. Identification of naturally infected Lutzomyia intermedia and Lutzomyia migonei with Leishmania (Viannia) braziliensis in Rio de Janeiro (Brazil) revealed by a PCR multiplex non-isotopic hybridisation assay. Trans R Soc Trop Med Hyg 99: 905-113.

PUGEDO H., BARATA R.A., FRANÇA-SILVA J.C., SILVA J.C., DIAS E.S. 2005. HP: um modelo aprimorado de armadilha luminosa de sucção para a captura de pequenos insetos. Rev Soc Bras Med Trop 38: 70-72.

READY P.D., LAINSON R., SHAW J.J. 1983. Leishmaniasis in Brazil: XX, Prevalence of enzootic rodent leishmaniasis (Leishmania mexicana amazonensis), and apparent plantations of introduced tree species and in other nonclimax forests in eastern Amazônia. Trans R Soc Trop Med Hyg 77: 775-785.

RANGEL E.F., LAINSON R. 2009. Proven and putative vectors of American cutaneous leishmaniasis in Brazil: aspects of their biology and vectorial competence. Mem Inst Oswaldo Cruz 104: 937-954.

RANGEL E.F., SOUZA N.A., WERMELINGER E.D., BARBOSA A.F. 1984 Infecção natural de Lutzomyia intermedia (Lutz \& Neiva, 1912) em área endêmica de leishmaniose tegumentar no Estado do Rio de Janeiro. Mem Inst Oswaldo Cruz 79: 395-396.

ROSARIO I.N.G, ANDRADE A.J., LIGEIRO R., ISHAK R., SILVA, I.M. 2017. Evaluating the Adaptation Process of Sandfly Fauna to Anthropized Environments in a Leishmaniasis Transmission Area in the Brazilian Amazon. J. Med. Entomol 54: 2017, 450-459 doi: 10.1093/jme/tjw182

SHERLOCK I.A. 2003. Importância médico veterinária. In: Rangel EF \& Lainson R (orgs), Flebotomíneos do Brasil, Fiocruz, Rio de Janeiro, 367p.

SILVA T.M.N., FREITAS R.A., SILVA D.F., ALENCAR. R.B. 2010. Fauna de flebotomíneos (Diptera: Psychodidae) de uma reserva de campina no Estado do Amazonas, e sua importância epidemiológica. Rev. Soc. Bras. Med. Trop. 43: 78-81.

SOUZA N.A., ANDRADE-COELHO C.A., VILELA M.L., PEIXOTO A.A., RANGEL E.F. 2002. Seasonality of Lutzomyia intermedia and Lutzomyia whitmani (Diptera: Psychodidae: Phlebotominae), occurring sympatrically in area of cutaneous leishmaniasis in the State of Rio de Janeiro, Brazil. Mem Inst Oswaldo Cruz 97: 759-765.

SOUZA C.F., BRAZIL R.P., BEVILACQUA P.D., ANDRADE-FILHO J.D. 2015 The phlebotomine sand flies faunain Parque Estadual do Rio Doce, MinasGerais, Brazil. Parasites and Vectors 8: 619-625.

TUOMISTO H., RUOLOLAINEN K., YLI-HALLA M. 2003. Dispersal, environment, and floristic variation of western Amazonian forests. Science 299: 241-244.

YOUNG D.G., DUNCAN M.A. 1994. Guide to the identification and geographic distribution of Lutzomyia sand flies in Mexico, the West Indies, Central and South America (Diptera: Psychodidae). Mem Am Entomol Inst 54: 1-881.

Received: 29/08/2016

Revised: $25 / 05 / 2017$

Accepted: 31/05/2017

Published online: 06/07/2017 